\title{
在宅患者に対する訪問栄養食事指導
}

\author{
中村育子
}

(医療法人社団福寿会 福岡クリニック在宅部栄養課)

\section{Visit nutritional guidance for patients at home}

\author{
Ikuko Nakamura
}

Fukuoka Clinic home care services, 7-18-11, Umeda, Adachi-ku, Tokyo, 123-0851

于123-0851 東京都足立区梅田 7-18-11

\begin{abstract}
The role of home-visit nutritional support is to collect information about nutritional issue during nutrition screening or assessment and to manage the plan of nutritional care for each case with inter-professional collaboration in home-care settings.

Registered dietitians counsel patients and/or their family for appropriate methods of nutrient intakes. They analyze the cause of anorexia gathering detailed information about nutrition issue from interview and observation of mealtimes.

To provide appropriate nutritional management services, it is important for the dietitians to understand living environment including the burden of caregivers, economic, and social factors. In home-care settings, these are several nutritional problems, which include the economic conditions, difficulty purchasing food, no exists cooker and unfit taste food.
\end{abstract}

These problems may cause anorexia or malnutrition according to decrease food intake and induce decreased quality of life (QOL) and activities of daily living (ADL) of the elderly patients at home.

The main aim of intervention by registered dietitian is to improve malnutrition related dysphagia and lifestyle-related diseases. Registered dietitian advises caregiver about cooking in order to promote the application of nutritional support programs. However, most of caregivers are elderly spouse with physical and psychological health problems. Thus, it is important to suggest them some simple recipes and menus considering burden among caregivers.

Suitable home-visit nutritional support program can improve their nutritional situation, QOL, and ADL for elderly patients living at home.

\section{1.はじめに}

現在, 超高齢社会の日本では段階の世代が75歳以上と なる2025年を目安に, 重度な要介護状態となっても, 住 み慣れた地域で自分らしい暮らしを人生の最後まで続け ることができるよう, 医療・介護・予防・住まい・生活 支援が一体的に提供される地域包括ケアシステムの構築 を実現している。今後75歳以上が急増するなか, 認知症 高齢者を地域で支えるためにも，地域包括ケアシステム は保険者である市町村や都道府県が地域の自主性や主体 性に基づき, 地域の特性に応じて作り上げていくことが
必要となる ${ }^{1)}$ 。高齢患者はさらに病院・施設から在宅へ 移行していくが, 入院の在院日数の短縮化により ${ }^{2)}$, 在 宅では急性期を脱したばかりで, 栄養状態の改善に至っ ていない患者が増加することにより，低栄養のリスクが

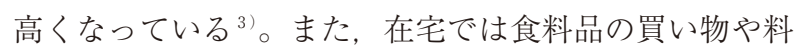
理を行う生活環境が整っていない場合も多く, 食環境の 悪化から栄養問題が増えるため, 管理栄養士の在宅患者 訪問栄養食事指導による栄養管理の需要が高まっている。 管理栄養士の在宅患者訪問栄養食事指導は, 医療機関 の管理栄養士が医療保険, 介護保険を使って月 2 回を限 度に指導料を算定することができるシステムである。病

$10(10)$ 

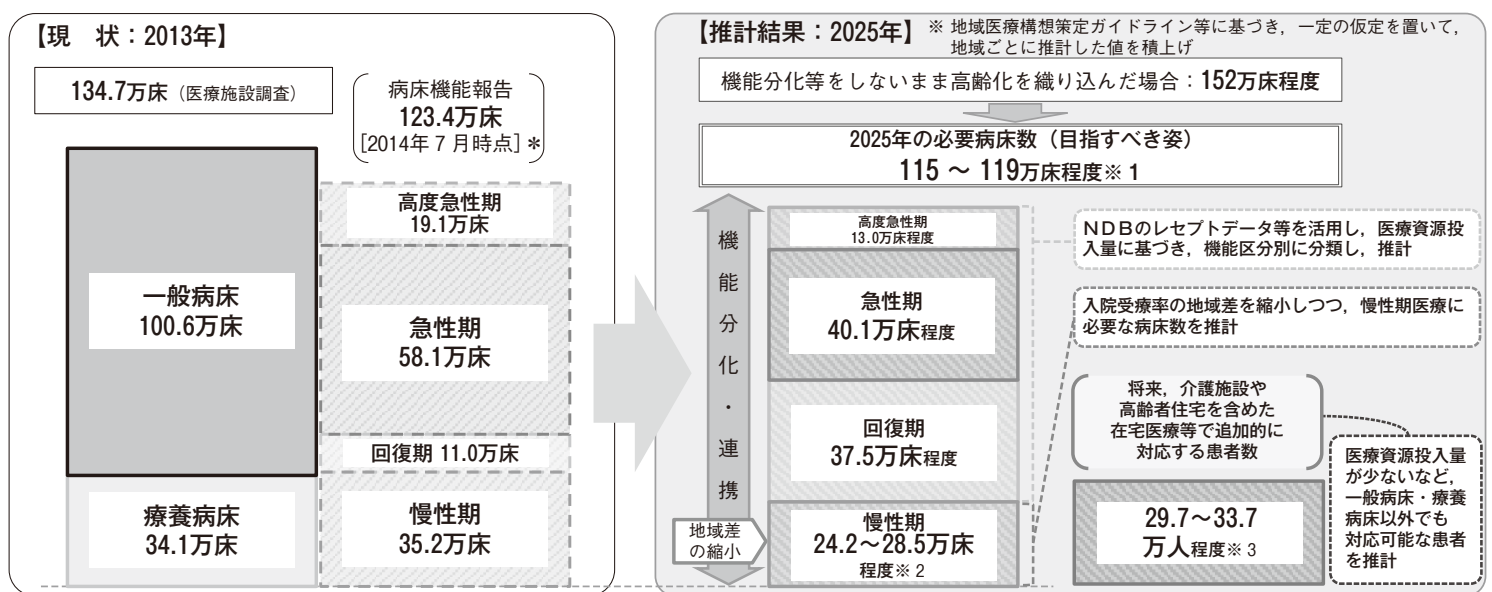

図 1 2025年の医療機能別必要病床数の推計

（厚生労働省：地域医療構想策定ガイドラインょり）

院から在宅に患者が州る場合や, 病院から施設を経てリ ハビリテーションを行った後で在宅に帰る場合, 在宅患 者訪問栄養食事指導を行う管理栄養士は, 患者が在宅で 継続して安定した状態が保てるよう食支援を行う必要が あり, 退院前カンファレンスや退院後のサービス担当者 会議で多職種連携する必要がある。

地域包括ケアシステムでは高齢化の進展に伴う医療の 変化に対応するため, 都道府県は平成27年度から地域医 療構想の策定作業を進め, 2025 (平成37）年に向けて, 急性期と慢性期の病床の機能分化や連携を推進すること が求められて㧍り, 厚生労働省は2016年 3 月に地域医療 ガイドラインで地域の実情に応じた急性期, 慢性期機能 と在宅医療等の需要推計を行うための推計方法を提示し た（図 1)。ガイドラインを踏まえて推計された2025年 の必要病床は115 119万床で, 今後 10 年間で最大約 20 万 床の病床削減となる予測を立てている。現状よりも急性 期病床を減らし, 回復期病床を充実させるが, 慢性期病 床についても10万床の削減を目指している。こうした機 能分化をすすめることで介護施設や在宅医療で対応する ことになる患者は $30 \sim 34$ 万人と推計されており, 在宅を 支える医療体制のあり方について早急な対応が求められ ている゙๋。

\section{2. 在宅患者の現状と在宅患者訪問栄養食事指導}

超高齢社会の日本では, 現在65歳以上の人口は 3,000 万人を超えており（国民の約 4 人に 1 人），今後も 75 歳 以上の人口割合は増加し続けることが予想されている5 。 在宅の変化は家族世帯の変化が大きく, 三世代世帯は減 少傾向にあり, 単独世帯, 夫婦のみ世帯, 未婚の子ども と親の世帯が増加傾向となっている。1980年では三世代 世帯の割合が一番多く全体の半分程度を占めていたが, 2013年では夫婦のみの世帯が一番多く, 約 3 割を占めて おり, 単独世带と合わせると半数を超える状況である ${ }^{6)}$ (図 2)。

高齢者は65〜 74歳までの前期高齢者と75歳以上の後期
高齢者では, 65〜 74歳で要支援認定者は1. 4\%, 要介護 認定者が3. $0 \%$ であるのに対して, 75歳以上では要支援 認定者 $8.4 \%$, 要介護認定者 $23.0 \%$ となって抢り, 後期 高齢者では要介護認定を受ける人の割合が大きく上昇し ている。しかし介護者の内訳では配偶者（男性 $31.3 \%$, 女性 $68.7 \%$ ）が一番多く, 介護力の低い老々介護が主流 となっている（図 3 )。高齢介護者の場合, 介護負担が 大きいと，介護者が先に倒れることもあるため，患者本 人にとって好ましい食事も重要であるが, 介護者の介護 負担軽減に貢献できる食支援が課題となっている。

現在の在宅療養は介護保険サービスを用いてもサービ スが不足している状況であり，生活援助（買い物，掃除， 調理等) については, 今後さらにサービス時間の短縮等 が行われると予測されている。自費でホームヘルパーを 雇える場合は問題ないが, 自費でホームヘルパーを雇え ない場合は, 生活するために必要なサービスが带り, 生 活環境が悪化する。在宅では 1 日 3 回の食事が必ず提供 されるという保証はなく, 在宅患者の栄養状態は生活環 境に大きく影響を受ける。経済状況, 食材の購入が困難, 食事を作ってくれる人がいない，作ってもらった食事や 弁当が口に合わない等, さまざまな栄養問題が山積して いる。そこから食欲不振, 食事摂取量の低下による栄養 状態の悪化や低栄養につながり, ADL (activities of daily living), QOL (quality of life) の低下につながっていく。 管理栄養士による在宅患者訪問栄養食事指導は, 栄養入 クリーニング, 栄養アセスメントにより栄養問題を抽出 し, 問題解決となるよう栄養ケアを多職種連携して作成 する。食欲不振の原因は何なのか, 本人・家族へのきめ 細かい聞き取りや食事観察から, 問題点を抽出していく。 問題点は管理栄養士だけで解決できるものではないため, 関係職種と連携する。経済的問題の場合はサービス担当 者会議に福祉事務所の生保ワーカーに来てもらったり， 口腔内に問題がある場合は歯科診療の必要性をケアマネ ジャーや家族に伝えて導入してもらうよう働きかける。 誤嚥のリスクが高く, 夜寝る前の口腔ケアを行う人がい 

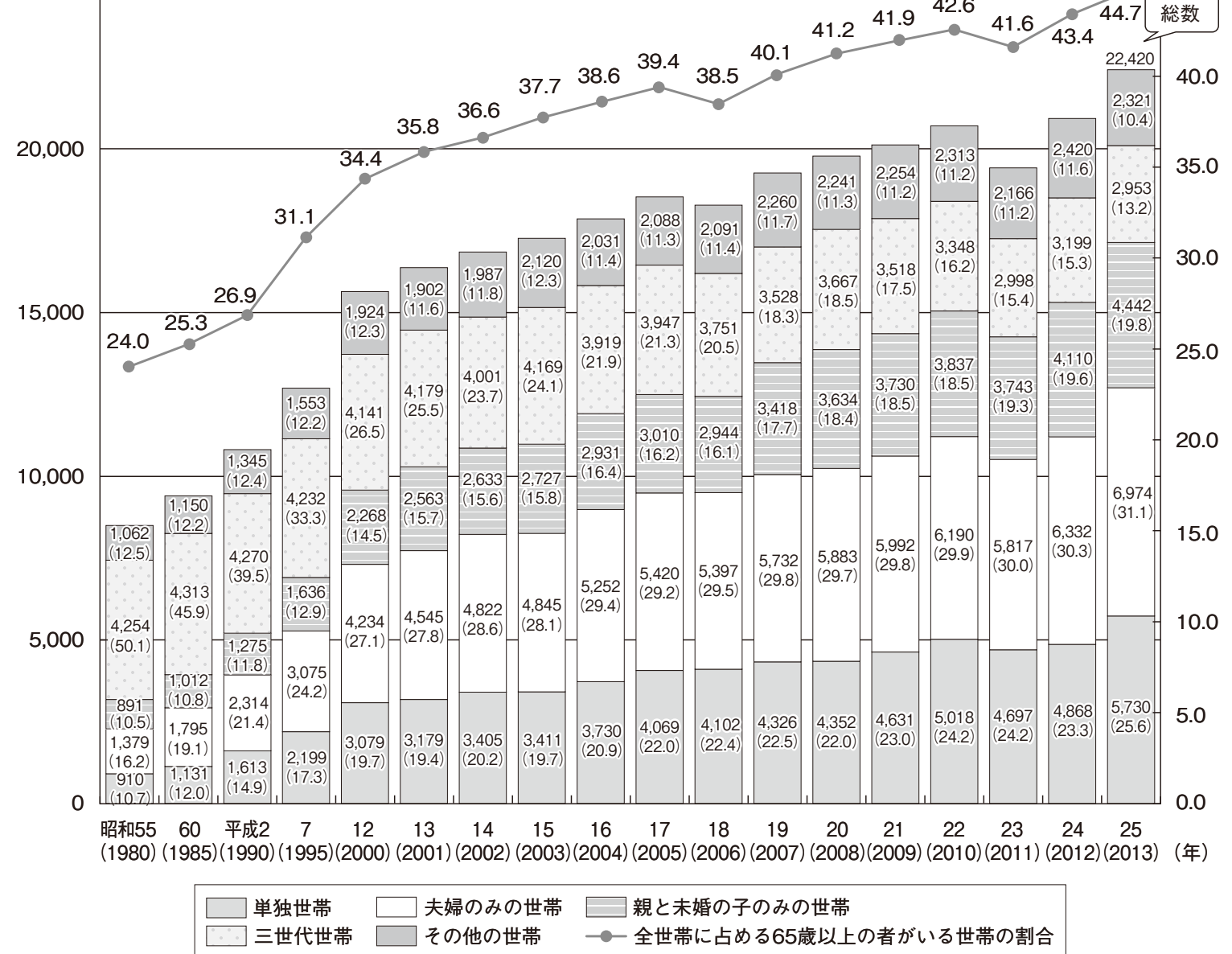

(内閣府：平成27年版高齢社会白書 より)

図 2 高齢者の家族と世帯

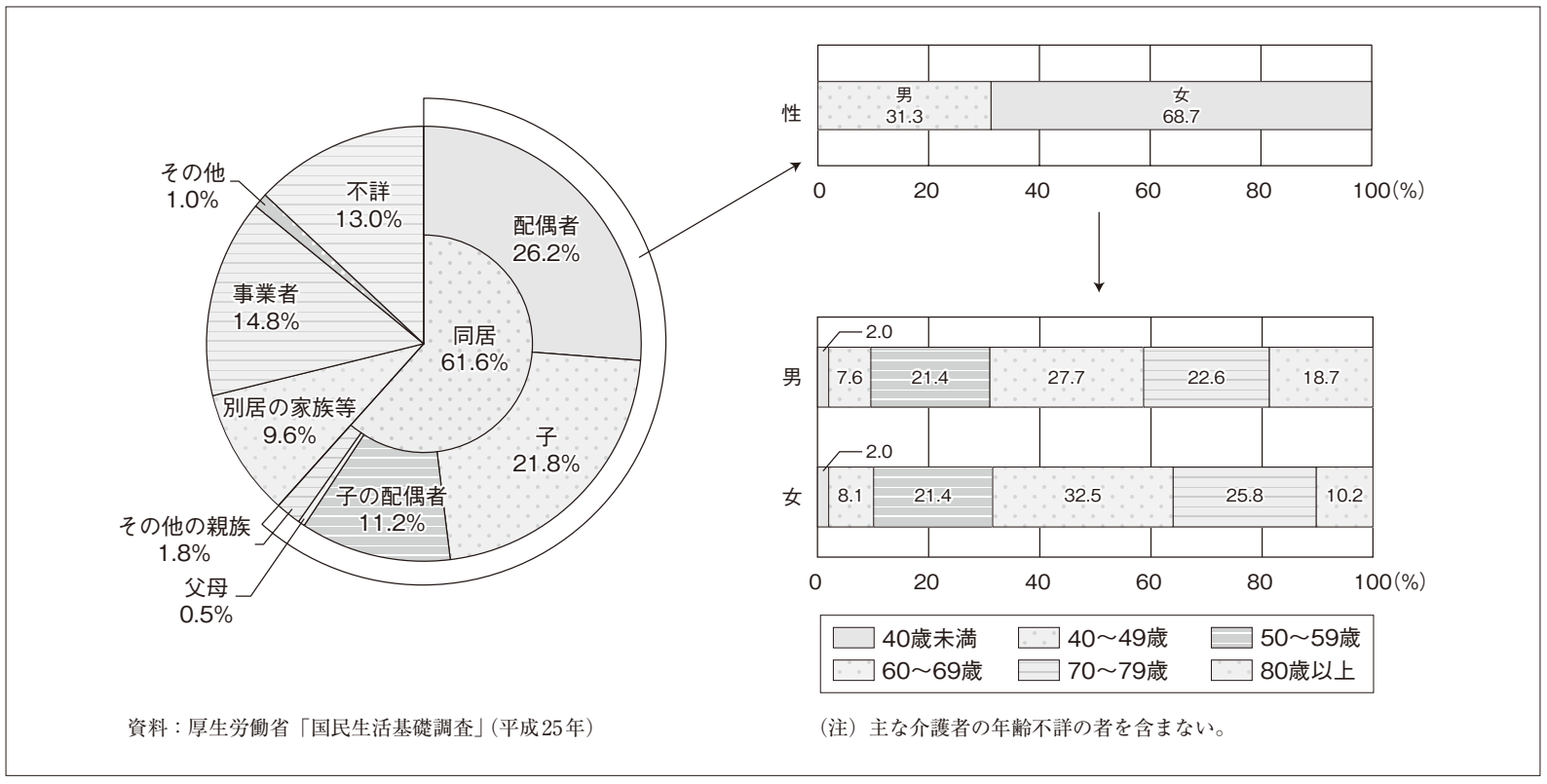

(内閣府：平成27年版高齢社会白書より) 

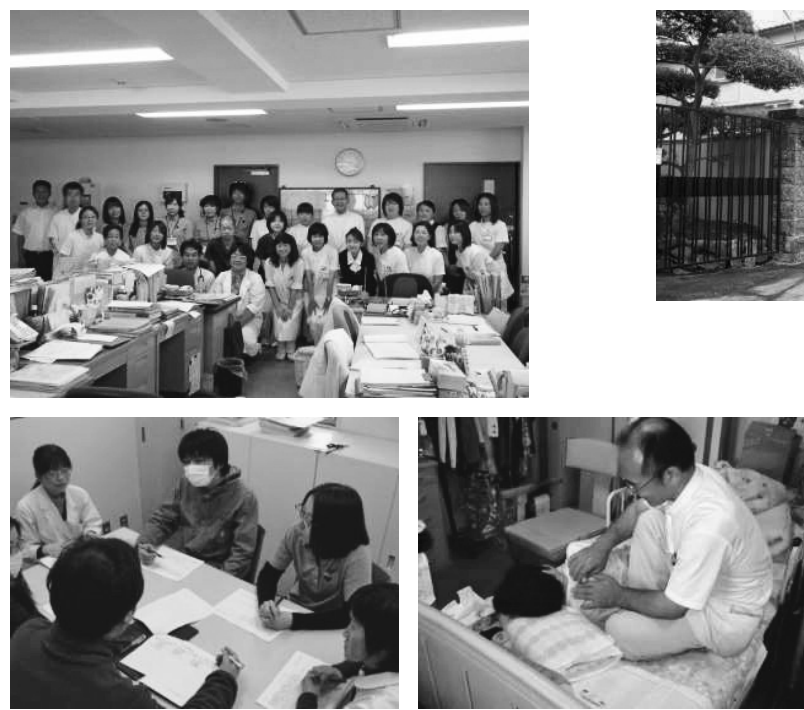

図 4 福岡クリニック在宅部 *在宅療養支援診療所：在宅患者数約 600 名
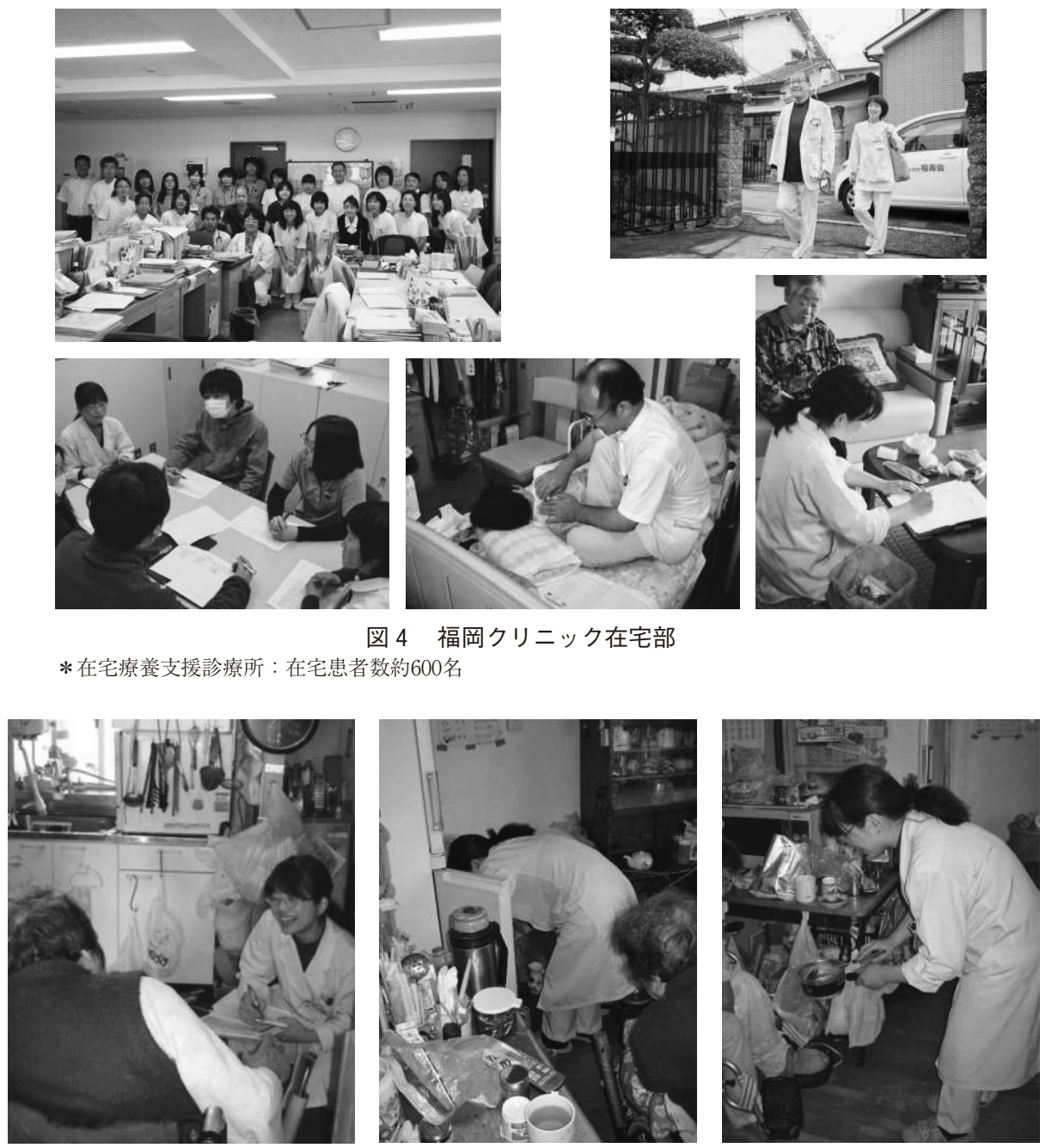

図 5 在宅訪問栄養食事指導

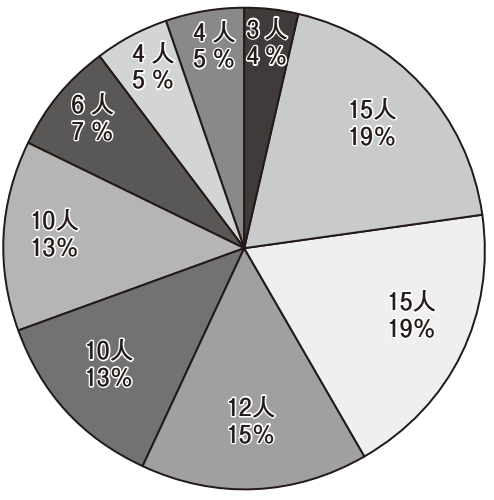

図 6 特別食の内訳

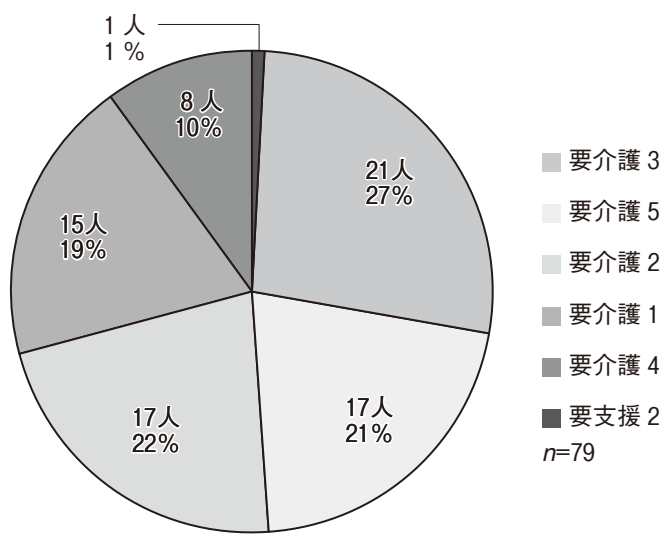

図 7 介護度
なければ，家族間で話し合って，誰かに来てもらう。問 題点を改善し, 少しでも生活環境が良くなり, 栄養状態 が改善するよう食支援を行う。

\section{3. 当法人の取り組み}

医療法人社団福寿会は東京都足立区にあり, 必要なと きに, 必要な人へ, 必要なだけ, トータルにサービスを 提供している。福岡クリニック在宅部は, 24時間在宅診
療を行っている在宅療養支援診療所であり，医師（内科， 整形外科, 神経内科, 皮膚科, 泌尿器科), 看護師, リ ハビリテーション (理学療法士, 作業療法士, 言語聴覚 士), 管理栄養士, 相談員, 事務員が所属し, 約600名の 在宅患者が元気に生活できるよう多職種連携して支援を 行っている(図 4)。また, 法人内外の多職種とも在宅 NST 連携を行っており,「在宅医療は患者の価值観に敬 意を払い, 人生に寄り添い, 暮らしの中でいのちを支え, 
生き方を支援する医療活動である」 ${ }^{7)}$ という基本理念を もとに在宅部スタッフは在宅訪問を行っている。

現在の在宅は病院の入院期間の短縮化に伴い, 急性期 を脱したばかりで急変しやすい患者, 疾病の重症化した 患者, 重度の摂食・䜩下障害者, 癌のターミナル患者が 増加してきている。状態は不安定で急変も多く見られて いる。在宅患者が慢性期疾患の多かった昔と比べて，重 症化している現状に伴い, 訪問栄養食事指導の介入方法 も個別対応を行う必要がある。摂食・臙下障害の重度化 では，病院からゼリー食で退院してくる患者が出てきて おり，家族に負担の大きいゼリー食の作り方を指導して いる。重度な摂食・嚥下障害患者が増えてきた 8 年ほど 前より, 在宅部栄養課では日本歯科大学口腔リハビリ テーションと連携し，摂食・嚥下障害があり，食事形態 が不明な在宅患者宅に歯科医師が訪問し嚥下内視鏡 （VE：videoendoscopic evaluation of swallowing）検査を 行い，與下の評価をしてくれるシステムを構築している。 この検査時は，ケアマネジャー，訪問看護，訪問介護， 通所デイサービス，ショートステイ先施設等の関係職種 に声をかけ，同席してもらい，患者が在宅・通所・施設 のどこにいても同じ食事形態で安全に食事ができるよう にしている。

現在，在宅患者訪問栄養食事指導の訪問件数は月に約 110件で, 対象者は79人である。在宅で栄養食事指導を 行っている写真を示した（図 5 )。年齢の平均值 \pm SD

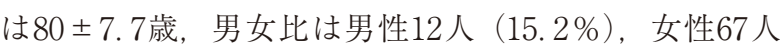
(84.8\%) であった。医師の特別食の指示内訳について 示した（図 6 )。摂食・嬹下障害を含む低栄養と生活習 慣病（糖尿病食，脂質異常症食，貧血食，腎臓病食，高 血圧食, 高度肥満）が混在している。介護度の内訳につ いても示した（図 7 ）。介護者の内訳については現在, 半数を居住系施設に訪問している。在宅では配偶者, ホー ムヘルパー，子どもの順であった。

当院で在宅患者訪問栄養食事指導を受けている対象者 の平均年齢は後期高齢者であり，男女比は圧倒的に女性 が多く，摂食・䐵下障害からの低栄養や生活習慣病がみ られた。また介護者は配偶者が多く，配偶者も要支援で
あったり，白内障で目が見えにくかったり，耳が聞こえ にくかったりと，生活に何らかの支障がある場合も多く， 介護力が低い状況であった。

\section{4.おわりに}

管理栄養士の在宅患者訪問栄養食事指導で大切なのは, 介護力が低下した家族の介護負担の軽減を考慮すること である。介護者である家族の介護負担が少なくなるよう, 食事作りにおいても，簡単においしい料理が作れるよう に，調理指導を行う必要がある。ホームヘルパーにおい ても現在の介護保険サービスでの生活援助で，手のかか る料理を作る時間はないのが現実である。在宅患者訪問 栄養食事指導を行う管理栄養士は在宅患者の生活環境全 般をカルテのアナムネや相談員, ケアマネジャー, ホー ムヘルパー等関係職種から情報を提供してもらい，本 人・家族とよく話をしながら，スクリーニング，アセス メントを行って問題点を抽出し, 患者の栄養状態を改善 するために問題点をどのように改善するのか, 長期目標, 短期目標，目標を達成するための栄養ケアを行う。栄養 ケアではさまざまな視点による多職種連携を行う。診療 報酬改定において国は在宅患者訪問栄養食事指導料の算 定要件を増やし緩和している。その期待に応え，管理栄 養士が適切な栄養介入を行い，どのような成果を上げら れるのか, エビデンスを構築することが求められている。

\section{文献}

1）厚生労働統計協会編：図説国民衛生の動向2014/2015, 厚 生労働統計協会, 東京, pp.39-44（2014）

2 ) 国立長寿医療研究センター編：平成24年度老人保健健康 増進等事業 在宅療養患者の摂食状況・栄養状態の把握に 関する調査研究報告書, 国立長寿医療研究センター, 愛知, pp.13-14 (2014)

3 ）内閣府：平成27年版高齢社会白書, pp.24-29（2015）

4) 佐々木昌弘, 武久洋三, 石田光広 : 特集地域医療構想と 介護，月刊介護保険， 8，12-19（2015）

5 ）総務省統計局：人口推計（平成 26 年 10 月 1 日現在), pp. 1 - 6 (2015)

6 ）内閣府：平成27年版高齢社会白書, pp.13-19（2015）

7 ）在宅医療テキスト編集委員会編：在宅医療テキス卜, 在 宅医療助成勇美財団，東京，pp. 8-11（2013）

本稿は，第51回研究集会における発題講演をまとめたものである。 